\title{
Understanding Marginality: Recent Insights from a Geographical Perspective
}

\author{
Steve Déry, Walter Leimgruber, Walter Zsilincsar
}

\begin{abstract}
Marginality and marginalisation have been researched extensively, especially during the 1960s and 1970s within the context of rapid urbanization in Latin America, mostly to try to find out who is marginal and who is not. But most researchers stumbled on the complexity of the phenomenon of marginality. Drawn from a geographical perspective, this note brings together research results presented in 2010, and coming from up-to-date fieldwork research in various regional contexts. Trying to find out common denominators, it highlights the importance of scale and perspective in considering marginality, as well as changes in power relations, the very basis of the marginalisation process.
\end{abstract}

Key words: marginality, geography, scale, power, systems, integration

\section{Razumijevanje marginalnosti: suvremeni pogledi iz geografske perspektive}

Koncepte marginalnosti i marginalizacije uvelike se istraživalo posebice 60 -ih i 70-ih godina 20. stoljeća u kontekstu nagle urbanizacije u Latinskoj Americi, ponajviše kako bi se otkrilo tko je marginalan, a tko nije. No većina istraživača pritom je nabasala na problematiku kompleksnosti fenomena marginalnosti. Polazeći od geografske perspektive, ovaj rad objedinjuje istraživanja iz 2010. te suvremena terenska istraživanja više različitih regionalnih konteksta. U pokušaju svođenja problematike na zajednički nazivnik u radu se naglašava važnost razine i perspektive u proučavanju marginalnosti te posebice promjenâ u odnosima moći, koje su ključne u procesu marginalizacije.

Ključne riječi: marginalnost, geografija, razina, moć, sustavi, integracija

\section{INTRODUCTION}

From July $4^{\text {th }}$ to July $10^{\text {th }} 2010$ the International Geography Union (IGU) Commission on "Globalization, marginalization, and regional and local response" (C08-27) gathered during an itinerant conference held both in Graz (Austria) and Fribourg (Switzerland). Given the location of the conference, it was organised around the theme "Mountain Areas and Globalization" (hereafter called "the Conference"). Six specific topics were proposed to the participants.

1. Regional policies and strategies

2. Ageing societies: ghettoization in mountain areas 
3. Agricultural niche productions and regional labels

4. Mountain regions and new technologies

5. Biodiversity

6. Natural hazards and human response

In the end, most papers were dealing with regional policies and strategies, probably because this topic was broader and more encompassing. After the conference, it was proposed to the participants to contribute to the production of a research note that would summarize the main collective findings raised from the discussion during the conference.

After this introduction this note is divided into three parts. The second part presents a few insights about research on marginality during the twentieth century and on how marginality has been put back into the research agenda from the 1990s onwards. The third part deals more directly with the outcomes of the 2010 conference to see what progresses have been made in understanding of the terms and concepts of marginality and marginalisation. Methodology is simple. We have examined the various case studies and tried to extract what were the common features considering how to define marginality, how to measure it, and what are the consequences of its augmentation. The fourth part focuses on regional policies and strategies to underline how the authorities at various levels perceive and tackle marginality. It also examines the effectiveness of some of the measures targeting marginality put in place.

\section{MARGINALITY: PUTTING IT BACK INTO THE RESEARCH AGENDA?}

\section{Between sociologists and geographers}

When one thinks about marginality, multiple and various images flash before one's eyes, as personal souvenirs or from media proxy: the "marginal" that we were as a teenager (or that we wished to be or that we have met); poverty scenes from all around the world that appear live on TV screens or on the Internet; climatic extremes which discourage everybody but a few eccentrics; forests, even tamed, which are still provoking atavistic angst; shades and night, when the anti-world (Brunet and Dollfus, 1990) awakes: drugs, violence, prostitution, etc. Marginality is an extremely broad term. All these phenomena, these people, these states of life, these spaces, and these times of life, do they really bear testimony to marginality? And if so, how? What do they have in common?

When looking at the specific literature on marginality (authors who directly tried to define marginality, at least partially), a first striking observation is that geographers and sociologists are turning blind eyes to each other. On the one hand, space appears rather marginal if not excluded from sociological analysis (Lewis, 1966; Nun, 1969; Lomnitz, 1977; Germani, 1980; Gonzales de la Rocha et al., 2004; Xanthakou, 2004) while, on the other hand, geographers do not pay much attention to what sociologists have to say (Vant, 1986; Leimgruber, 2004) ${ }^{1}$. This situation may explain why theoretical interpretations of what marginality is and how to measure it are still not satisfying ${ }^{2}$.

Marginality appeared as a concept in the scientific community in the first half of the $20^{\text {th }}$ century. In 1928, Robert Park identified immigrants as marginal due to their disparities (Park, 1928), while, in 1937, Edwin Stonequist noted that "the marginal person dragged between two or more social worlds, and that the harmonic and attractive, repellent and 
complicated aspects existing in both of the two worlds, caused different reflections in the spirit of the individual" (Nabavi 2009, 351). According to Dennis (Dennis 1991, 4 cited in Dennis, 2007) this model in the studies of marginality lasted "until Dickie-Clark (1966) introduced the term "marginal situation" and moved the discussion from the personality of the marginalized to a more pointedly sociological reference point. (...) The importance of Dickie-Clark's approach, however, gave credence to the argument that marginality was more nuanced, complex, and multidimensional than had been assumed" (Dennis, 2007). Thus, from the 1960s, research on marginality found fertile ground in the struggle against inequalities in urban Latin America. The debate over the marginalization theory during the 1960s, 1970s, and soon after, was mostly confined to "case" or situation studies. Yet, efforts were made to enlarge this approach (Lewis, 1966; Nun, 1969; Lomnitz, 1977), but none of those who examined this question, even Germani who wrote a whole book about marginality (1980), were successful in explaining the many flaws relating to how marginality was defined at the time, especially on the fringe, to the very limits of marginality. A possible explanation for this incapacity to define marginality well probably lay in the fact that these researchers dealt with marginality through a "binary" approach. It was conceived as a state where "you are" or "you are not", 0 or 1, marginal or not marginal. Looked at from perspective, we can say that the concept was condemning itself to be locked up. Lomnitz, for one, was not able to resolve questions concerning the "blurriness of the borderlines" (Lomnitz 1977, 13); for example, the "foreman of a construction gang ... [who] earns more ...; yet he remains a member of the marginal strata...." (Lomnitz 1977, 13). Lomnitz admitted his incapacity to decide in which category to put this guy. More recently, works by Dennis introduced the idea of a dual marginality "suggested as a multidimensional approach" to "rescue marginality from a theoretical cul-de-sac" (Dennis, 2007). Although, Dennis' approach was based on the situation of black youth in the southern part of the US, caught on the one hand between their parents guidance and their wills as teenagers, and on the other hand between their small black community and the larger white community. In the end, this analysis reveals only... two dimensions (Dennis, 2007). Clearly, from our point of view, there is a need for a more encompassing set of explanations, encompassing more than just an aggregation of various social situations. What does it mean to be marginal? Are there observable similarities in all situations of marginality? What is the smallest common denominator of all these identified social patterns where marginality appears or is identified?

But is it relevant to follow this path? Is marginality a "pseudo-idea" or a "non-idea", as De Koninck has critically evoked as there is a market for ideas, especially those which are avoiding tackling fundamental problems (De Koninck, 1980)? Even if marginality is a very broad concept as said above, some trends emerge from recent work and form solid grounds on which we can even go further in order to "tackle fundamental problems".

Geographers, at least until recently when a commission was mandated by the International Geographical Union (IGU), did not focus strongly on this topic (see Vant, 1986 and the recent studies published by the aforementioned commission: Jussila et al., 2001; Jussila et al., 2002; Leimgruber et al., 2003; Leimgruber 2004; Leimgruber et al., 2010). Ideas emerging from these works allow us to find new paths to understand marginality. In particular, Leimgruber, after having gathered and aggregated much data about 
marginality, concluded that, in the end, there were still three forms of marginality that were worth studying: geometrical, systemic, and processual (Leimgruber 2004, 56). According to him, geometrical marginality is similar to peripherality and refers to Von Thünen's model, where "marginal is the point where profit turns into loss - marginal regions reduce themselves to a geometric line. None of the land use rings is marginal because each is logically defined" (idem).

As for systemic marginality "not to be confused with systems marginality" (Leimgruber 2004, 62), Leimgruber, referring to Mehretu, Pigozzi and Sommers (2002), underlines how some systems have inherent forces creating inequalities, systems in which privileged groups are favoured in the distribution of goods and services, in the allocation of political roles, irrespective of the individuals' competence (Leimgruber 2004, 62).

Then, Leimgruber refers to Mehretu's approach who names "processual marginality" the result of a process, intentional or not, in a system of production, the Fordist or post-Fordist capitalist system (Leimgruber 2004, 61). In the same wake, Mehretu and his colleagues add "contingent marginality" produced by market forces and competition, which creates marginal people, region or countries (idem, 62).

Though, in the end, even if this approach remains incomplete, it underlines at least three aspects of marginality on which we can build, if we compare to previous approaches. First, Leimgruber considers that observations on marginality are valid only at a certain spatial resolution: "It is a question of scale at which we want to study marginality" (Leimgruber 2004, 59); second, marginality is a question of perspective, of point of view; third, drawing on Kirk (Kirk, 1980), Leimgruber finds difficult to identify a clear demarcation between non-marginal and marginal and make his case using the distinction between town and countryside, showing how this distinction is most of the time blurred.

\section{Going further}

A first question that has not been answered convincingly until now is how to measure marginality. This issue appears important not for the sake of numbers, but for at least one reason. Supposedly, from previous studies, some were able to identify, sometimes from numbers (for example income) who is marginal and who is not marginal: at the level $\mathrm{x}$ dollars per year, you are marginal, and at $\mathrm{x}+1$, you are not. This raises the question to find where is the point between these two; that is where one becomes marginal or not marginal. Gino Germani already accepted that there may be some "partial marginality" (Germani, 1980), but actually, we would point to the fact that marginality is always partial, somewhere in-between, since no one can be fully marginal or fully "not-marginal" (our case studies provide examples of this idea); marginality is always "grey" (Déry, 2010a). Hence, there should be a point where one crosses the fence; then again, there should be some measure of marginality or of non-marginality, when one is closer or further from the "fence" - otherwise, we are condemned to work with constant "blurriness". This dilemma is similar to the one around the urban-rural dichotomy (and of threshold values in general): where do towns and villages begin? Statistics alone (number of inhabitants) do not help.

The second item to point out from previous approaches to marginality is that they fail to bring together in the same analysis the various situations of marginality. Lomnitz's 
example (1977), over which he stumbled, represents exactly the challenge to overcome. How to put in the same analysis the fact that a foreman is the boss of his construction gang, thus retaining a certain amount of power, while at the same time, he remains part of the lower classes when he is compared to the executives of his company? Leimgruber (2004), using Mehretu, noticed the questions of scales and perspectives, but without trying to integrate them into one analysis.

We now suggest that the only way to overcome this difficulty is to use a multilevel systemic analysis approach, and that this analysis should consider both time and space. The market system studied by Mehretu is indeed creating marginality; but in fact, it is composed of a multitude of sub-systems in which power relations as well as marginality vary. The same individual who is clearly marginal in a system appears not marginal at all in another of which he is part at the same time.

In studying how capitalism is working today, this approach has the advantage to show how capitalism is gaining more and more power in the sub-systems of the overall market system, in the very cells, where reproduction is happening, and where also possibilities to revolt still exist. A better understanding of marginality through this system approach certainly will allow a better understanding of how the power is evolving between the systems and the sub-systems, where the new "territories" to conquer are, and what the new battlegrounds are.

\section{CHARACTERISING MARGINALITY AND MARGINALISATION}

During the 2010 Conference of the Commission, at least eight participants tried to characterise or evoked specific features of marginal situations using various case studies. They refer to the relative character of marginality, varying according to scales or to systems. Some have found it in discourses, mostly based on linked assumptions while others have insisted on the marginalisation process which they see as a decline from a previous situation.

\section{Scales and relativity}

From four quite different case studies, Margarita Schmidt (Argentina), Firuza Begham Binti Mustafa (Malaysia), Walter Zsilincsar (Austria) and Steve Déry (Vietnam) confirmed the importance of considering systems and scales in the understanding of marginality. Firstly, Schmidt tried to show the change in specific variables related to viticulture and viniculture in the Uco Valley, province of Mendoza, Argentina (cultivated area, cultivated varieties, area of vineyards according to age, size of vineyards, conduction system, volume of wine production, origin of the invested capital, oenological quality of the grapes, etc.). She considers that what contributes to the marginality of the inhabitants of this valley are not only a lower development level, but also an insufficient integration, as well as the widening and deepening of the local structural heterogeneity. The latter appears as a "collateral result", and "raises the interrogation if the progress experienced by the region creates developments that are advantageous for all or only for some, without a simultaneous process of inclusion" (Schmidt, 2010).

In the same wake, secondly, Zsilincsar, studying the evolution of niche products like the Styrian pumpkin (from which seed-oil can be made), concludes that marginality is not 
necessarily restricted to the outer edges or fringes of an area. In this case, Styrian pumpkin producers became less marginal for a time when their niche products hit the market; but they then receded back to some form of marginality when competition entered the market. Also, this study has shown how the level of marginality varies according to the perception: while the pumpkin producers - and their region as a whole - may be seen as marginal from the outside, this perception does not coincide with how local people perceive themselves (Zsilincsar, 2010). The apparent paradox here simply lies in the fact that these two perceptions do not refer to the same system; they neither refer to the same territorial organisation nor to the same time frame: outsiders see Styria within a larger system and give more importance to this latter, while local producers give more importance to the role they play within their local sub-system.

If we compare this to the third case study presented by Begham about Malaysian shrimp farmers, the same scale variation appears. Although, in Begham's case, the situation is worse for local people as they are marginalised not only in the economic system in which they participate, but also at the local level because their ecological base has become badly eroded (Begham, 2010).

This situation is also highlighted in Déry's synthesis and assessment of how mountains in mainland Southeast Asia have been integrated to the various national and international systems during the past few decades (Déry, 2010b). Especially, the globalisation, integration and commoditisation processes have all contributed to diminish the power of local people even in the sub-systems close to them. For example, the implementation of protected areas in most of this region has forced local people, by their own will, government projects or from private investments, to integrate national and international economic systems, within which their decision power has often diminished considerably (see also Déry, 2007, 2008 and 2011).

\section{Marginality emerging from a decline}

At least two case studies described marginality as a result of a process of decline, actually a process of marginalisation. In two different contexts, Olli Lehtonen and Markku Tykkylaïnen (Finland) and Yasutaka Matsuo (Japan) observed that relative economic and population decline in rural communities was leading to marginality. In the first case, Lehtonen and Tykkylaïnen compared various rural areas to try to understand why some of them were able to cope with changing economic situations, while others were experiencing a sharp decline in the number of jobs, population, as well as in economic dependency in general. This decline was mainly due to a failure to adapt to the new economic conditions, often in rural areas where the economic structure is dependent on primary resources. Also, the relative proximity to larger centres is crucial (Lehtonen and Tykkylaïnen, 2010). In other words, they use the world-system theory, according to which each state or region is positioned in the world system at its centre, periphery or semi-periphery, the whole system being structured by power relations (Leblond, 2010). In Japan, some mountainous rural areas are so depopulated that specific governmental programmes have been designed to target the new needs of residual population. In some areas, the Kaso programmes - a term which means literally "too sparsely populated" - have been in effect for more than 50 years. Here again, areas depending on primary resources, such as agriculture and forestry, 
are those that have been affected the most. In many places, a partial abandonment of the villages is under way (Matsuo, 2010).

In these two cases, what is striking is how the decline observed in rural areas is linked to the way these same areas have been integrated into the national or international systems. Those who failed to integrate are those who were not able to adapt to the new emerging context, and who lose power in the way they interconnect in the new systems. This clearly means that these specific local systems have lost partially, or maybe completely - this remains to be observed or studied - their relevance.

\section{How to measure marginality?}

None of the papers presented at the Conference addressed directly the question of how to measure marginality, although, many contributors did evoke this issue in some way. Actually, methods of measuring marginality can be divided into two main groups: either through qualitative analysis or through quantitative analysis. Some researchers have also used both methods in their research.

On the qualitative side, Leimgruber insists on the fact that marginality is not just related to a distance from a large urban centre - a geometrical aspect - since one can also found "uninteresting" regions close to urban areas (Leimgruber, 2010). In his thoughts about protected areas in Switzerland, "marginality in the mind" can "be observed indirectly through people's behaviour to nature" (Leimgruber, 2010). Zsilincsar's analysis goes in the same wake: interviews with regional farmers and representatives of the Chamber of Agriculture in Styria (Austria) revealed perceptions about how marginal they felt or not, but "a quantitative measurement [within this context] turned out inappropriate if not impossible" (Zsilincsar, 2010). On a different kind of basis, Déry's research in Vietnam, even if it implies the possibility of measuring marginality (see above), examines the evolution of power relations in the processes that are affecting local people. This means that, for now, it is possible to determine whether an individual or a group has lost some decision power or not, and this process could be seen as a marginalisation process (that is a process in which marginality increases) (Déry, 2010b).

On the quantitative side, Lehtonen and Tykkylaïnen measured the augmentation of marginality using the number of jobs lost in relative terms in a given community (Lehtonen and Tykkylaïnen, 2010). In itself, from our point of view, the loss of jobs is not sufficient to give a true measure of marginality. It is when the "labour potential" is coupled with the diversity of the economic structure and the relative location of a community that a loss in the diversity of jobs could almost certainly testify to a decrease in the decision power in a community. In the context of mountainous rural Japan, Matsuo also used population data, coupled with the number of households and the industrial transaction amount to measure marginality in rural areas. Here the down spiral of the forestry industry has created an economic structure in which local people have become more and more dependent on "policy support" (i.e. subsidies) or on out-migration; the level of these subsidies being somehow a kind of measure of marginality (Matsuo, 2010).

Schmidt, in her case study of Argentina has used both qualitative and quantitative factors to measure marginality. The method is based on the comparative analysis of the 
variables, both within the broader context and the local dynamics during the last 20 years, in order to detect the adaptation processes of the activities, of the pre-existing and the new actors and the resulting transformation of the territory (Schmidt, 2010). These indicators are then compared in a wider context - regional, provincial - in order to grasp the "relative nature of marginality" (Schmidt, 2010). Thus, they "try to find out if the incorporation of new global actors in the local community and in the local agricultural and industrial activities has produced a transformation of the conditions in the Uco Valley" (Schmidt, 2010).

In a quite different context Firuza Begham used both kinds of indicators. In the fishing villages she studied, she analyses how the loss of the access to the sea (a qualitative change) and the perceptible decline in fish catches (quantitative) have reinforced each other to marginalise the local villagers (Begham, 2010).

In all these case studies, the interesting point is that we can identify a smallest common denominator to the marginalisation process: in each case, there is a significant change in the power relations, that is how the relations of some individuals or a group within a given system are changing (in Zsinlincsar, Lehtonen and Tykkylaïnen, and Matsuo cases) or when these people are integrating into new (larger) systems in which the adaptation appears problematic (in Schmidt, Begham and Déry's cases).

\section{ASSESSING AND RESPONDING TO MARGINALITY: THE MEDICINE WORSE THAN THE EVIL?}

One of the questions asked of the participants in the call for papers before the conference was to examine how governments or authorities were tackling marginality, at least when they identified people or regions in this situation. None of the participants directly addressed this question but a few papers have contributions that can be merged around one issue: the marginalising effect of the integration process.

From the case studies, it has been witnessed that regional policies and strategies may cause marginality to augment (marginalisation) when investments from outside are "poured" or attracted into a given region (Schmidt, Déry, Begham). These regional policies are not alleviating marginality, even if they can contribute to reduce "some characteristics of lower development and insufficient integration" because they create a tension between a "globalised and a traditional world" (Schmidt, 2010). Matsuo also found that some measures are "effective enough to mitigate or lessen the difficulties" (Matsuo).

Some cases span a longer period of time. In Austria, Zsilincsar found that, at first, some local producers were trapped in a marginalisation process when they were more integrated to the international market. Although, later on, their marketing strategies, like "the creation of niche products", helped some of them to reduce their marginality within the same system (Zsilincsar, 2010). In this wake, Zsilincsar thinks that "effective responses to marginalization can be offered only on a case related, rather small to medium scale area of investigation" (Zsilincar, 2010). Lehtonen and Tykkylaïnen faced almost the same situation in Finland where those who were able to exit the marginalisation process were those who overcame the "stagnation of skills and knowledge" (Lehtonen and Tykkylaïnen, 2010). Getting new skills and new knowledge to be able to cope with the new 
(or changing) systems is what Déry also found in mainland Southeast Asia: those who were the better off after the integration process started were those who either got "assets" from the start, or those who were able to rapidly get new ones, including especially skills and knowledge (Déry, 2010).

\section{PROBLEMS AND LIMITS IN MARGINALITY STUDIES}

Finally, to study marginality and the marginalisation process inevitably meets with problems.

A first difficulty which emerges from the very beginning is how to define the process. In this regard, the contribution made by Steve Kale is interesting. From his case study in the United States of America, he highlights the fact that the assessment of marginality, and thus responses to reduce it, depends on who defines it (Kale, 2010). This means that not only marginality in itself is a political and sometimes even geopolitical question (see also Leimgruber's case study, 2010), but also, its definition and the way it is used to implement programmes of various kinds. Tracing a line between those who are marginals from the point of view of those who define it, clearly constitutes a political action.

Also, amongst the problems is the lack of evidence. Schmidt's and Matsuo's case studies lean towards the identification of a marginalisation process, though they recognize that their studies remain incomplete to a certain extent. Finally, Zsilincsar also stressed the difficulty of "coining" marginality to measure it effectively. Déry has underlined this problem in an earlier working paper drafted in 2005 (Déry, 2005).

\section{CONCLUSION: WHAT KIND OF CONTRIBUTION FOR STUDIES ON MARGINALITY}

This research note builds on Déry's reflexion about marginality (Déry, 2010a) as well as on contributions made by participants at the International Geographical Union (IGU) Commission on "Globalization, Marginalization, and regional and local response" (C0827) itinerant conference held in July 2010.

Three main points could be highlighted from the various case studies used in this note. First, some marginalisation processes have been triggered by the integration of the targeted population into larger systems, systems within which their decision power has diminished, thus augmenting their level of marginality. What is clear enough now is that, paradoxically, integration may signify marginalisation.

Second, though none of the presentations during the 2010 conference addresses the issue of how to measure marginality, the certainty that marginality is continuously changing (augmenting or diminishing) left open the door for more research in this field and try to figure how to "see" these changes.

Third, the transformation of local conditions through the integration into new - mostly bigger-systems has underlined the question of how to adapt to these new conditions. When people are not able to cope with the new conditions, that is to learn the new skills or language deemed necessary to function within the new system, they are likely to be marginalised. 
What could be drawn from these main points is the fact that all situations of marginality or of marginalisation - the process which contributes to augment the level of marginality - are entangled in a maze of systems. The only way to grasp a better understanding of how this marginality is created, and how the power relations have changed to bear this result, is to use a multilevel or multisystem approach. That means to draw the portraits of the various systems within which an individual or a group is part, illuminating the power relations in each of these systems, and thus getting a more comprehensive idea of marginality for this individual or group. This could serve to examine with more accuracy how the local systems have lost (some or all of) their relevance and what impact this process can have on our societies as a whole.

\section{ACKNOWLEDGMENTS}

Steve Déry's work was supported by the Fonds Québécois de recherche pour la société et la culture [grant \#2005NP-106025]; and the Social Science and Humanities Research Council of Canada [grant \#410-2006-1325].

Even if they have not participated directly in the writing of this research note, the contributions of the following persons have been used to produce it (the papers they presented at the conference appear in the bibliography): Firuza Begham Binti Mustafa, Steve Kale, Yasutaka Matsuo, Margarita Schmidt, Olli Lehtonen and Markku Tykkylaïnen.

\section{NOTES}

1 This assertion is far from peremptory; it just emerges from the observation that there is no cross referencing between the authors cited here. Moreover, space is not really considered by the sociologists who tried to define marginality.

2 In a very recent initiative, the French journal Autrepart has published a thematic issue on "The city in front of its margins" (Autrepart, 2008). Though they do not examine the theoretical aspects of marginality, we can draw from the thirteen case studies some similar insights to those observed in the cases studied for this research note.

\section{REFERENCES}

Begham Binti Mustafa, F., 2010: Shrimp farming in Peninsular Malaysia: A study in globalization and marginalization. Paper presented to the Conference "Mountain Areas and Globalization" of the International Geography Union (IGU) Commission on "Globalization, marginalization, and regional and local response" (C08-27), Graz (Austria) and Fribourg (Switzerland), $4^{\text {th }}$ to $10^{\text {th }}$ July 2010.Brunet, R., Dollfus. O., 1990: Mondes Nouveaux, Hachette and Reclus, Paris.

De Koninck, R., 1980 : Les pieds, la tête et la géographie. Notes sur la fonction organique d'une discipline académique Implications (1), 33-46. 
Dennis, R. M., 1991: Dual Marginality and Discontent Among Black Middletown Youth Research in Race and Ethnic Relations (ed. Dennis, R. M.), 6 JAI Press, Greenwich (CT).

Dennis, R. M., 2007: Marginality Blackwell Encyclopedia of Sociology (ed. Ritzer, G.), Blackwell Publishing Blackwell Reference Online, London (http:// www.sociologyencyclopedia.com/subscriber/ tocnode?id=g9781405124331_chunk_g978140512433119_ss1-25) (13.07.2011.).

Déry, S., ed 2005 : Problèmes de développement dans les régions marginales. Une exploration des fondements de la marginalité, Department of Geography Université Laval (Les Travaux du GREDIN 1), Québec.

Déry, S., 2007 : Les parcs nationaux en Asie du Sud-Est, une manifestation de la transformation de l'État moderne. Le cas du parc national Cat Tien au Vietnam, Géocarrefour (82), 219-230.

Déry, S., 2008 : Les aires protégées, nouvel outil du dynamisme des États sud-est asiatiques?, Annales de géographie (117), 72-92.

Déry, S., 2010a: Studying marginality through a multiscalar grid: a case study from protected areas in Vietnam 2010: Geographical Marginality as a global issue: Papers presented during the Meetings of the Commission on Marginalization, Globalization And Local And Regional Response, 2004 - 2007, International Geographical Union, Commission C08-47 (eds. Leimgruber, W., Nel, E., Matsuo, Y., Binns, T., Chand, R., Cullen, B., Lynch, D., Pradhan, P. K.), Department of Geography University of Otago, Dunedin (CD-Rom).

Déry, S., 2010b: Globalization, Integration, Commoditization, and Marginalization: new Individuals, new Households, within new States. The Emergence of a new Geography in Mainland Southeast Asia, Paper presented to the Conference "Mountain Areas and Globalization" of the International Geography Union (IGU) Commission on "Globalization, marginalization, and regional and local response" (C08-27), Graz (Austria) and Fribourg (Switzerland), $4^{\text {th }}$ to $10^{\text {th }}$ July 2010.

Déry, S., 2011 : Aires protégées : quel rôle dans l'intégration des régions périphériques d'Asie du Sud-Est continentale?, Espaces protégés et territoires. Conflits et acceptation (eds. Laslaz L et al), Belin, Paris (in print).

Dickie-Clark, H. F., 1966: The Marginal Situation, Routledge \& Kegan Paul, London.

Germani, G., 1980: Marginality, Transaction Books, New Brunswick (New Jersey).

González De La Rocha, M., Jelin, E., Perlman, J. E., Roberts, B. R., Safa, H., Ward, P. M., 2004: From the marginality of the 1960s to the "new poverty" of today: a LARR Research Forum, Latin American Research Review (39), 183-203.

Jussila, H., Majoral, R., Cullen, B., eds 2002: Sustainable Development and Geographical Space. Issues of population, environmental, globalization and education in marginal regions, Ashgate, Aldershot.

Jussila, H., Majoral, R., Delgado-Cravidao, F., eds 2001: Globalization and Marginality in Geographical Space. Political, economic and social issues of development in the new millenum, Ashgate, Aldershot.

Kale, S., 2010: Regional Policies, Issues, and Strategies in Mountainous Areas of the U.S. Pacific Northwest, Paper presented to the Conference "Mountain Areas and Globalization" of the International Geography Union (IGU) Commission on "Globalization, marginalization, and regional and local response" (C08-27), Graz (Austria) and Fribourg (Switzerland), $4^{\text {th }}$ to $10^{\text {th }}$ July 2010.

Kirk, W., 1980: The rural-urban continuum: perception and reality Development of settlement systems, (eds. Enyedi, G., Mézaróz, J.) Akadémiai Kiadó (Studies in Geography in Hungary 15), Budapest, 11-19.

Leblond, J.-P., 2011 : 'Vers une transition forestière en Thaillande? Analyse causale de l'avancée des forêts à partir du cas de Phetchabun' Unpublished PhD Thesis Department of geography, Université de Montréal.

Leimgruber, W. 2004: Between Global and Local. Marginality and Marginal Regions in the Context of Globalization and Deregulation, Ashgate, Aldershot.

Leimgruber, W., 2010: National parks and protected areas - policies and strategies in Switzerland, Paper presented to the Conference "Mountain Areas and Globalization" of the International Geography Union (IGU) Commission on "Globalization, marginalization, and regional and local response" (C08-27), Graz (Austria) and Fribourg (Switzerland), $4^{\text {th }}$ to $10^{\text {th }}$ July 2010.

Leimgruber, W., Majoral, R., Chul-Woo Lee, eds 2003: Policies and Strategies in Marginal Regions. Summary and Evaluations, Ashgate, Aldershot. 
Leimgruber, W., Nel, E., Matsuo, Y., Binns, T., Chand, R., Cullen, B., Lynch, D., Pradhan, P. K., eds 2010: 2010 : Geographical Marginality as a global issue: Papers presented during the Meetings of the Commission on Marginalization, Globalization And Local And Regional Response, 2004 - 2007 International Geographical Union Commission C08-47 Department of Geography University of Otago, Dunedin (CD-Rom).

Lehtonen, O., Tykkylaïnen, M., 2010: Local rural economic development and resource dependency in Finland, 1994-2003, Paper presented to the Conference "Mountain Areas and Globalization" of the International Geography Union (IGU) Commission on "Globalization, marginalization, and regional and local response" (C08-27), Graz (Austria) and Fribourg (Switzerland), $4^{\text {th }}$ to $10^{\text {th }}$ July 2010.

Lewis, O., 1966: La Vida, Random House, New York.

Lomnitz, L. A., 1977: Networks and marginality. Life in a Mexican Shantytown, Academic Press, New York.

Matsuo, Y., 2010: Examining the supporting policies/measures in the light of present lifestyles of the residents in depopulated mountain areas in Japan, Paper presented to the Conference "Mountain Areas and Globalization" of the International Geography Union (IGU) Commission on "Globalization, marginalization, and regional and local response" (C08-27), Graz (Austria) and Fribourg (Switzerland), $4^{\text {th }}$ to $10^{\text {th }}$ July 2010.

Mehretu, A., Pigozzi, B. W. M., Sommers, L. 2002: Spatial shifts in production and consumption - marginality patterns in the new international division of labour, Sustainable Development and Geographical Space. Issues of population, environmental, globalization and education in marginal regions, (eds Jussila, H., Majoral, R., Cullen, B.), Ashgate, Aldershot 195-208.

Nabavi, S. A. H., 2009: Migrant, marginality and suburbanization, a conceptual framework European Journal of Social Sciences 9(2), 350-355.

Nun, J., 1969: Superpoblación relativa, ejercito industrial de reserve y masa marginal Revista latinoamericana de Sociología (5), 178-236.

Park, R. E., 1928: Human Migration and the Marginal Man American Journal of Sociology (33), 881-893.

Schmidt, M., 2010: Local transformations in mountain areas influenced by globalization. a case in Mendoza, Argentina, Paper presented to the Conference "Mountain Areas and Globalization" of the International Geography Union (IGU) Commission on "Globalization, marginalization, and regional and local response" (C08-27), Graz (Austria) and Fribourg (Switzerland), $4^{\text {th }}$ to $10^{\text {th }}$ July 2010.

Stonequist, E. V., 1937: The Marginal Man, Russell \& Russell, New York.

Vant, A., ed 1986 : Marginalité sociale. Marginalité spatiale, CNRS, Paris.

Xanthakou, M., 2004 : Marginalité Dictionnaire de l'ethnologie et de l'anthropologie (eds. Bonte, P., Izard, M., Abélès. M., Descola, P., Digard, J.-P., Duby, C., Galey, J.-C., Jamin, J., Lenclud, G.) Presses Universitaires de France $3^{\text {rd }}$ ed. Paris, Quadrige.

Zsilincsar, W., 2010: Specialisation and niche-products as a means for survival of small agrarian enterprises, Paper presented to the Conference "Mountain Areas and Globalization" of the International Geography Union (IGU) Commission on "Globalization, marginalization, and regional and local response" (C08-27), Graz (Austria) and Fribourg (Switzerland), $4^{\text {th }}$ to $10^{\text {th }}$ July 2010. 


\title{
Razumijevanje marginalnosti: suvremeni pogledi iz geografske perspektive
}

\author{
Steve Déry, Walter Leimgruber, Walter Zsilincsar
}

Koncepte marginalnosti i marginalizacije uvelike se istraživalo, posebice 60 -ih i 70-ih godina 20. stoljeća u kontekstu nagle urbanizacije u Latinskoj Americi, ponajviše kako bi se otkrilo tko je marginalan, a tko nije. No većina istraživača pritom je nabasala na problematiku kompleksnosti fenomena marginalnosti. Kako bi se riješio taj problem, savjetujemo upotrebu višerazinskoga sustavnog pristupa koji se sastoji od proučavanja i dodavanja istoj analizi različitih situacija uzimajući u obzir razlike u geografskoj razini proučavanja. Polazeći od geografske perspektive, ovaj rad objedinjuje rezultate istraživanja predstavljene na Konferenciji Komisije za globalizaciju, marginalizaciju i regionalni i lokalni odgovor (C08-27) Svjetske geografske unije (IGU) održanoj u Grazu (Austrija) i Fribourgu (Švicarska) od 4. do 10. srpnja 2010. Podaci su pribavljeni putem osam suvremenih terenskih istraživanja više različitih regionalnih konteksta: Argentina, Austrija, Malezija, Vijetnam, Finska, Japan, Švicarska i SAD. Metodologija je jednostavna: proučavanjem različitih studija slučaja nastojali smo pronaći zajednički nazivnik. Marginalizacija ponajprije (što i ne iznenađuje) varira s obzirom na razinu i perspektivu. Sama ta činjenica svakoga tko želi razumjeti marginalnost prisiljava na višerazinski pristup. Na isti način taj nam je sustavni pristup omogućio da shvatimo kako su promjene u odnosima moći u samoj srži procesa marginalizacije, tj. u povećanju razine marginalnosti pojedinca ili grupe. U nekim se situacijama pokazalo da marginalizacija raste nakon relativnog pada (u broju stanovnika, ekonomskoj aktivnosti), posebice u ruralnim područjima. Studije slučaja zatim su pokazale da dimenzije marginalnosti ostaju bitne i u kvalitativnom i u kvantitativnom obliku, ali da su potrebna daljnja istraživanja te treba ići dalje od upotrebe pomoćnih indikatora (poput poreza), koji ne upućuju izravno na odnose moći. Sljedeći aspekt koji se javlja jest činjenica da je identifikacija marginalizacije ili pitanje tko je marginalan politička odluka, zbog čega vrlo često programi ili akcije što nastoje "pomoći" marginalnima povećavaju marginalnost. Razlog je što ti programi pridonose integraciji pojedinaca ili grupa u veće sustave nacionalnih ili međunarodnih razmjera, ali njihovi autori ne razumiju da upravo ta integracija rezultira porastom marginalnosti.

Iz različitih studija slučaja upotrijebljenih u ovom radu mogla bi se izvući tri glavna zaključka. Prvo, neki procesi marginalizacije pokrenuti su integracijom ciljanih skupina u veće sustave, unutar kojih je oslabjela njihova moć odlučivanja, čime se povećala njihova razina marginalnosti. Sada je jasno da, paradoksalno, integracija može značiti marginalizaciju.

Drugo, iako se nijedna prezentacija na konferenciji 2010. ne bavi pitanjem kako mjeriti marginalnost, činjenica da se ona neprestano mijenja (raste ili se smanjuje) ostavlja mogućnost za nova istraživanja na tom polju i pokušaje otkrivanja kako "vidjeti" te promjene.

Treće, transformacija lokalnih uvjeta kroz integraciju u nove - uglavnom veće - sustave postavlja pitanje prilagodbe tim novim uvjetima.

Također se može zaključiti da su sve situacije marginalnosti i marginalizacije - procesa koji pridonosi porastu marginalnosti - upletene u niz sustava. Jedini način da se bolje razumije stvaranje marginalnosti te kako se odnosi moći mijenjaju i time utječu na marginalnost jest upotreba višerazinskog ili višesustavnog pristupa. To znači da je potrebno nacrtati portrete različitih sustava unutar 
kojih se nalaze pojedinci ili skupine, bacajući svjetlo na odnose moći u svakom od sustava, čime se dobiva jasnija ideja marginalnosti tih pojedinaca ili grupe. To se može upotrijebiti za preciznije određivanje kako lokalni sustavi gube važnost i kakav učinak taj proces ima na naše društvo u cjelini.

Received (Primljeno): $2011-11-18$

Accepted (Prihvaćeno): 2012 - $05-23$

Steve Déry, Associate Professor

Laval University

Quebec City

(Quebec) Canada

Steve.Dery@ggr.ulaval.ca

Walter Leimgruber, Emeritus Professor University of Fribourg

Switzerland

walter.leimgruber@unifr.ch

Walter Zsilincsar, Emeritus Professor

University of Graz

Austria

walter.zsilincsar@uni-graz.at 